\title{
What Do 'Lay' People Know About Justice? An Empirical
} Enquiry.1

\begin{abstract}
When mediation places decision-making power in the hands of lay disputants it raises troubling issues. Can justice be delivered without judicial assistance? What is the effect on the legal system? And how should outcomes thus achieved be regarded? Critics have tended to answer negatively, pointing to a range of harms including individual oppression and the vanishing trial.

Such views, focusing too narrowly on conformity to legal norms, overlook ordinary people's capacity for justice reasoning. A recent Scottish pilot study of small claims mediation parties illustrates the richness and complexity of their thinking around whether, and for how much, to settle. This suggests that mediation settlements, rather than representing second-class justice, may enhance the legitimacy of the legal system. Implications for theories of justice are considered.
\end{abstract}

Key words: alternative dispute resolution; mediation; justice; natural law theory; lay people; empirical research on an earlier draft of this article. 


\section{1) Introduction}

Mediation as a social process is elegantly simple: two people who disagree turn to a third for help. Yet its adoption by contemporary Western justice systems raises complex questions: who is responsible for mediation outcomes and by which criteria should they be evaluated? This article considers an important strand in current debates: how fair and how just are mediation outcomes? Perhaps equally importantly: who is entitled to decide what constitutes justice?

Much of the critical scholarship on mediation comes from the legal academy (see literature review at 2 below.) Given lawyers' key gatekeeping role in disputes this scholarship has been influential in fuelling scepticism about a process that places decision-making authority in the hands of ordinary people (Irvine, 2010). Concern about non-lawyers' ability to deliver just results seems to start early in a legal career. A first year law student wrote: 'One of the major drawbacks of mediation is that lay people are in control of justice' (Irvine, 2015). Indeed. A few months of legal education were clearly sufficient to set this this nascent professional apart from 'lay' people (Erlanger and Klegon, 1978).

My purpose is not to re-run arguments about mediation's superiority or inferiority to litigation. Rather it is to draw attention to the reflex dismissal of non-lawyers' capacity for justice. Induction into the legal profession seems to efface the swathes of history, philosophy and literature (not to mention war) animated by the human sense of justice and injustice. Ignorance of legal rules becomes ignorance, full stop. The justice system can be considered a 'regime of truth' (establishing what is true, how to distinguish true 
from false and who has power to make that judgment) (Foucault 1980, cited in Shiner 1982, 384). 'Those who occupy the lowest status in the various institutions and conditions of life - the patient, inmate, prisoner, welfare mother, labourer, student - all find their knowledge discounted' (Shiner, 1982, 384). To this list could be added the lay litigant (Quintanilla, Allen and Hirt, 2017).

How might we view the outcomes from a justice event in which the primary decisionmakers are not legally trained? Rather than dismissing mediation as second class justice (Frey, 2000; McGregor, 2015), I propose extending the ambit of its promised empowerment and self-determination to include outcome justice. First I review themes from the scholarly literature on mediation and justice, noting practical and philosophical concerns, before describing ADR developments in Scotland, one of the jurisdictions least receptive to such processes. This article then draws on the early findings of an empirical study into the justice reasoning of lay mediation participants. The sample is small, but it is not the purpose of qualitative research to draw conclusions about wider populations. It aims, rather, to explore complex and difficult questions in a way that is credible, authentic and critical (Whittemore, Chase and Mandle, 2001; Webley, 2010). The participants shed new light on ordinary people's thinking about fairness and justice.

This article's intention is twofold: first, to draw attention to the richness of lay people's justice reasoning, countering its simplistic characterization as 'subjective' or selfserving; second, to suggest that mediation outcomes resulting from that reasoning warrant serious consideration within the justice system. That is not to say that they are immune from error or injustice, but rather that these decisions are generally animated 
by many of the same considerations judges apply in civil cases: fairness, retribution, restitution, proportionality, teaching someone a lesson and even making a public example of them (Maroney, 2012).

I conclude that critiques of mediation's justice capabilities have focussed too narrowly on conformity to legal norms, particularly given the impossibility of accurately evaluating outcomes without running a full trial (Menkel-Meadow, 2006). A broader conception of justice, acknowledging non-legally qualified people's interest in and capability for justice reasoning, is more likely to judge mediation on its own terms, as animated by principles of empowerment and self-determination. Fuller asserted: 'A serious study of mediation can serve, I suggest, to offset the tendency of modern thought to assume that all social order must be imposed by some kind of "authority", (1971, 315). I will argue that mediation provides an alternative normative order by offering ordinary citizens a forum to negotiate not only the outcomes to their disputes but the criteria by which those outcomes are evaluated. Natural law theory, rather than legal positivism, may provide a way of conceptualising results arrived at through human rationality.

\section{2) Mediation and Justice}

When mediation was first adopted by Western justice systems expansive claims were made regarding its benefits: it would be faster, less expensive and more inclusive; (Sander, 1985) more democratic (Bush and Folger, 1994; Mayer, 2012); gentler (Bok, 1983); empowering (Beer and Packard, 2012); and help preserve relationships (Moore, 
1986; Haynes and Haynes, 1989). It quickly spread across the USA, thanks in part to Sander's (1985) vision of the 'multi-door courthouse'.

Such ringing endorsements provoked an inevitable backlash; around the same time a number of academic commentators held mediation up to a more critical light. This wave of scholarship is captured in Abel's (1982a) collection, 'The Politics of Informal Justice,' though others entered the fray (Nader, 1979; Auerbach, 1983; Fiss, 1984; Delgado, 1988; Luban, 1995). Many of the scholars most critical of alternatives to the formal justice system were equally critical of the system itself, influenced by the critical legal studies movement. Their arguments, most of which remain 'largely unchallenged' (Roberts and Palmer, 2005, 9) are set out below.

At the heart of academic critiques lies the accusation that alternative forms of dispute resolution fail to deliver justice, providing instead: "poor justice to the poor" (Abel 1982, cited in Cappelletti, 1993, 288, fn 19). More recently a prominent UK scholar asserted:

It does not contribute to substantive justice because mediation requires the parties to relinquish ideas of legal rights during mediation and focus, instead, on problem-solving.... The outcome of mediation, therefore, is not about just settlement it is just about settlement [emphasis in original] (Genn, 2012a, 411).

In assessing the purported justice of dispute resolution processes, the adversarial system and resultant judicial determinations tend to be presented as the gold standard (Nader, 1979; Fiss, 1984; Luban, 1995). Lawyer-negotiation, mainstay of the justice system, 
is tolerated as 'bargaining in the shadow of the law' (Mnookin and Kornhauser, 1979). Mediation, however, is portrayed as a rogue process: unregulated, private, informal and, potentially, unfair (Frey, 2000; Genn, 2012b). Four persistent critiques can be identified in the literature: a) informalism, b) sources of norms, c) confusion of fairness and justice, and d) the distinction between procedural and substantive justice.

\section{a) Informalism}

The first wave of critical thinking about ADR tended not to distinguish mediation from other non-court processes such as arbitration; all were seen as 'informal'. While informality had its attractions, critics were quick to point out its drawbacks.

i) Neutralising conflict.

Nader argued that consumers were short-changed by informal processes, whose caseby-case approach left systemic abuses by powerful corporate interests unchallenged and unscrutinised (Nader, 1979). Others were concerned about losing the deterrent impact of such scrutiny (Singer, 1979; Budnitz, 1994). Abel claimed: 'informal institutions neutralize conflict by responding to grievances in ways that inhibit their transformation into serious challenges to the domination of state and capital' (Abel, 1982a, 280). From this perspective, processes designed to reduce or resolve conflict play into the hands of elites whose interests lie in maintaining the status quo. Similar concerns are voiced by those who see mediation aiding neo-liberal efforts to privatize and depoliticize the justice system (Resnik, 2002; Cohen, 2009a). Such critiques come from the left, political home of the critical legal studies movement (Delgado et al., 
1985). They raise questions of their own: must a process deliver social equality to be considered just? And is that standard applied to courts and tribunals? (Silbey, 2005)

ii) Expanding the reach of the State

Abel discerned a more sinister side-effect of well-intentioned efforts to empower communities through mediation. Authorities could thereby 'seek to review behavior that presently escapes state control' $(1982,272)$. Harrington $(1982,63)$ employed almost opposite logic to assert that referrals to mediation amounted to 'delegalization', expanding the reach of the state by removing these matters from judicial scrutiny. Others accused governments of seeking to co-opt mediation (Menkel-Meadow, 1991; Engle-Merry, 1993; Coy and Hedeen, 2005), although such views may underestimate mediation's potential to support resistance to state power (Mulcahy, 2000).

iii) Removing protection from the disadvantaged

Critics were also concerned about the loss of procedural protections, claiming that informal processes 'provide advantaged plaintiffs with a sword to enforce their rights while denying disadvantaged defendants an equivalent shield' (Abel, 1982, 296). Engle-Merry observed judges and lawyers framing low value disputes as moral dilemmas, 'offering lectures and social services rather than protections or punishment' (1990, 1). Grillo (1991) made a highly influential claim that mediation's informality particularly disadvantages women and minorities (Menkel-Meadow, 1997). Others have reached similar conclusions (Delgado et al., 1985; Noone and Ojelabi, 2014), although Reda (2010) distinguishes feminist critiques of mediation from 'first wave' critiques such as Abel's in their focus on individuals rather than structure. 


\section{iv) Loss of law}

Fiss added a further complaint about the loss of legal formality: we lose the benefit of public judgments in developing societal norms, 'reducing the social function of the lawsuit to one of resolving private disputes' (Fiss, 1984, 1085). These sentiments have been echoed by scholars concerned about diluting the courts' function in enunciating public norms (Luban, 1995; Weinstein, 1996; Resnik, 2002; Perschbacher and Bassett, 2004, Cohen, 2009b). Fiss's arguments have been revived by UK academics (Genn, 2012b; Mulcahy, 2013) and adopted by senior judiciary (Leveson, 2015; Lord Thomas of Cwmgiedd, 2015; Ryder, 2015). All deplore the potential harm caused by diverting cases to ADR and an 'anti-adjudication and anti-law discourse' (Genn, 2012a, 409). Genn's views convinced the Scottish Civil Courts Review to limit judicial encouragement for mediation (Irvine, 2010).

This argument follows a seam of US scholarship on the 'Vanishing Trial', even though its author concedes that the reduction in full hearings is 'not confined to sectors or localities where ADR has flourished' (Galanter, 2004, 519). The vanishing trial has been critiqued for reflecting the justice industry's prejudices: 'Like medieval astronomers who mapped the Earth as being the center of the universe, most professionals in the legal system - including lawyers, judges, and legal scholars place the courts in the center of the world of conflict resolution'(Lande, 2005, 199).

This brief survey of the first wave of mediation critics highlights a range of issues bearing on justice and injustice: does mediation allow the powerful to evade scrutiny, bring government into more of our lives, work against the powerless and undermine a functional litigation system? Two unarticulated premises seem to underpin them all: 
1) The legally disadvantaged - lay, unrepresented, poorly educated or simply poor lack the ability to assert their own needs and to produce results that are fair and just. This empirical question will be discussed in part 3 .

2) The courts are the appropriate source of normative authority to be applied in disputes. This is both a political and philosophical matter and will be discussed in the next section.

\section{b) Legitimate sources of norms in litigation and mediation}

In common law systems courts derive norms from two principal sources: legislation and judicial precedent. Both claim authority. Parliaments can point to their electoral mandate; courts to the logic of legal reasoning in real cases (although this has been questioned: Schauer, 2006). In principle things are equally clear-cut for mediation. Norms pertaining to outcome come from the parties and the mediator's role is confined to process (Haynes and Haynes, 1989; Mayer, 2012; Moore, 2014). In this vision, whether a settlement is just or unjust is none of the mediator's business: the principle of self-determination leaves parties free to arrive at any outcome they choose (Stulberg, 2005). Scholars, however, have questioned the empirical reality (Greatbatch and Dingwall, 1989; Coben, 2004) and theoretical desirability (Rifkin, Millen and Cobb, 1991; Astor, 2007; Mayer et al., 2012) of mediator neutrality.

An alternative approach would be to see mediators as a potential source of normative guidance. Riskin contrasts the 'facilitative' style, where mediators assume parties can solve their own problems given a helpful process, with the 'evaluative' style, where mediators with legal expertise believe their evaluation will help parties achieve 
settlement (Riskin, 1996, 2005).. The evaluative/facilitative debate has had huge resonance within the mediation community (Wall and Chan-Serafin, 2014; Rubinson, 2016). An alternative view is that wider social norms guide parties' decision-making (Waldman, 1997; Belhorn, 2005). Waldman divides mediators into 'norm-generating' ('disputants... generate the norms that will guide the resolution to their dispute') (p. 708), 'norm-educating' (mediators provide normative guidance but parties ultimately decide) (p. 727) and 'norm-advocating' (mediators ensure outcomes conform to legal or regulatory norms) (p. 745). Both Riskin and Waldman acknowledge that mediators may change style from context to context, suggesting a situational dimension to any mediator guidance.

Some see legal information or advice as the guarantee of informed consent (NolanHaley, 1999; Korobkin, 2005). For others this is impractical and wrong: if anything trumps self-determination, even the mediator's sense of fairness or justice, party autonomy is compromised (Stulberg, 1998; Bush and Folger, 2005). A key battleground in these debates is the appropriate source of normative guidance in mediation. Scholars have tended to assume that such guidance can only come from the 'juridical field,' characterised by Bourdieu as 'the site of competition for monopoly of the right to determine the law' (1987 p. 817). It includes judges, lawyers and jurists: 'an entire social universe which is in practice relatively independent of external determinations and pressures' (p. 816). It may conceivably include lawyer mediators providing evaluative guidance.

Little attention has been paid to parties themselves: what weight, if any, should be granted to their justice judgments? Do they look to mediators to inform them about 
social and legal norms? Or do they see themselves as best placed to select the standards by which mediation outcomes should be evaluated? Put more simply, can we, should we and do we trust lay people to decide what is fair and just?

c) Justice and fairness

i) Etymology

Much of the discussion above employs the terms fairness and justice interchangeably. Yet the two English words have distinct tones of meaning. 'Justice' derives from French and Latin, languages of the King and the court, of authority and officialdom. 'Fairness', on the other hand, is a Norse word originating in the visual qualities of a longboat's 'fair' payload (Wilson and Wilson, 2006). It is everyday and self-evident, not dissimilar to reasonableness (Wheeler, 2014). Anyone may have a view on fairness, whereas justice embodies the means by which the state applies and enforces the law: it is the prime Aristotelian virtue (Reid, 2008), the 'virtue of the magistrate' (Aristotle, no date). Fairness, then, is 'bottom-up,' a universal urge but subjective standard; justice is 'top-down,' emanating from societal elites yet aspiring to set universal standards.

Most have little difficulty in accepting that ordinary people understand fairness, while regarding justice as the domain of legal professionals (a view echoed in Bourdieu's (1987) critique of the juridical field). Little wonder, then, that critics express concern when legal systems adopt processes allowing lay people to determine outcomes, a role hitherto reserved for state-appointed judges.

ii) Criteria for evaluating justice and fairness 
Some scholars see litigation as the benchmark for the quality of justice achieved in mediation (Sabatino, 1998; Frey, 2000); others see the two processes as alternatives, justice in court coming from 'above', mediation being more 'horizontal' (Hyman and Love, 2002, 160) or 'justice from below' (Stulberg, 2005, 5). A related debate asks whether mediators should tilt the justice playing field to protect the ostensibly less powerful party. Responses range from not at all (Stulberg, 2012); through a relatively thin vision where mediators intervene where agreements 'are so one-sided and unfair that they shock the conscience' (Waldman and Ojelabi, 2016, 423); to acceptance of mediator influence to ensure compliance with legal norms (Carmichael, 2013). Like their critics, those defending mediation's fairness credentials appear to echo 'the complacent assumption among jurists that state law is the most influential source of normative order in society' (Tamanaha, 2019, 173).

Even where attention is paid to non-legal norms the mediator is often presented as guarantor of fairness, while parties' views are characterised as subjective (Hyman, $2014,34)$ or merely the opinions of 'lay' people (Schwartz, 1999; Shestowsky and Brett, 2008). Colatrella proposes twin standards: first, an outcome "is "fair" if the participants deem it acceptable'; second, the mediator must find it 'sufficiently and substantively fair too' $(2014,715)$. Waldman differentiates 'self-determination theorists' from 'social norm theorists', the latter less optimistic about human capacity to reach just decisions and more concerned about inequality and power $(2004,250)$.

d) Procedural and substantive justice 
Genn's complaint about mediation focused on its capacity to deliver 'substantive justice' (Genn, 2012a, 411). This describes the outcome of a process; the fairness of the process itself is known as procedural justice. Across multiple cultures and contexts procedural justice is a more reliable predictor of party satisfaction than substantive justice (Brockner et al., 2001; Lind, 2001; MacCoun, 2005; Solum, 2005; Tyler, 2006; Bollen, Ittner and Euwema, 2012; Nolan-Haley and Annor-Ohene, 2014). Despite critiques of its conclusions on the grounds of confirmation bias (Silbey, 2005), attribution errors (Collett, 2008) and research design (Creutzfeldt and Bradford, 2016) this research offers evidence of what people value in dispute resolution processes:

i. Voice: the opportunity to present views, concerns and evidence to a third party (Brockner et al., 2001; Lind and Arndt, 2017)

ii. Being heard: the perception that the 'third party considered their views, concerns and evidence' (Welsh, 2001, 820)

iii. Treatment: dignified and even-handed (MacCoun, 2005).

Unsuccessful litigants are more likely to rate themselves satisfied when they believe they have been fairly treated: 'fair procedures are a cushion of support against the potentially damaging effects of unfavourable outcomes' (Tyler, 2006, 101). Welsh (2001) believes mediation can offer a procedurally fair experience, leading parties to feel valued and respected.

e) Conclusion: a critical response to the critics

These scholarly debates should give pause to even the most starry-eyed mediation enthusiasts. A recurring concern is that participants with the least bargaining power will end up with 'less' than they would have received from a judge. Does this mean 
that mediation should not be practised when one party is disadvantaged in some way? How would disadvantage be measured? Below average income? Failing to attain a certain educational level? The range of potential disadvantages could include gender, cultural heritage and structural factors like occupying a lower place in an organisational hierarchy (Delgado et al., 1985; Seth, 2000).

One contextual factor often overlooked by mediation's critics is that those with least power and resource are also unlikely to fare well in the courts (Wexler, 1970; Sarat, 1990). It is not simply a matter of income poverty: Galanter famously set out the range of practical and systemic challenges faced by 'one-shotters' pitched against 'repeat players' in litigation, severely limiting the courts' redistributive capacity $(1974,97)$. Sandefur (2008) identified a range of complex, interrelated factors limiting poor people's successful use of legal institutions, including social status, feelings of disentitlement and previous negative experiences. Studies highlight the impact of poor or no representation on outcomes (Seron et al., 2001; Yoon, 2009; Quintanilla, Allen and Hirt, 2017). In an imperfect world mediation may deliver less than perfect justice; but so may litigation and other processes touched by the logic of the market.

The notion of obtaining 'less' raises further problems. By what criteria should outcome be evaluated? And by whom? To ensure the disadvantaged do not do worse than at trial, a mediator would require a judge's legal knowledge and the means to take evidence under oath and probe competing accounts. One may as well run the trial.

And if the mediator does tilt the playing field to protect the ostensibly weaker party, inescapably she tilts it against the other party. Mediation's critics have paid little 
attention to 'advantaged' participants; here again, how to measure advantage? Rhetoric on this issue often juxtaposes a poor, unrepresented individual with a major utility or multinational bank. But legal claims can equally involve two small businesses; or a self-employed tradesperson and a retired professional couple; or an SME in financial difficulty and a late-paying customer. Who is disadvantaged and, once again, who should decide? More pragmatically, if mediators make efforts to support one party, how will the other party view a process that claims to be consensual yet seems weighted against them? Mediation's credibility is unlikely to be enhanced by moves depriving one of its participants of even-handed treatment, a key dimension of procedural justice.

Most problematic of all is that the 'less' critique fails to judge mediation on its own terms. Mediation claims to empower participants to make informed choices. This goes beyond simple preference: mediators generally invite people to choose not only the outcome to their dispute but the criteria by which that outcome is evaluated (Waldman, 1997). This complex form of thinking involves finely-tuned judgements about personal and community norms as well as factors like expectation, risk, commitment and personal resources. Little attention has been paid to that thinking.

Mediation scholarship appears to have fallen into the habit of assuming that 'lay' people's lack of legal knowledge effaces their capacity for thinking about substantive justice. Studies involving participants tend to focus on factors such as satisfaction, improved relationship and procedural justice (Wissler et al., 2002; Eisenberg, 2016; Charkoudian, Eisenberg and Walter, 2017). Where substantive justice is considered, the views of lawyers predominate (Genn et al., 2007), fulfilling Bourdieu's prediction 
that the juridical field maintains its monopoly through 'the disqualification of the nonspecialists' sense of fairness' (1987, p. 828).

It is thus timely to investigate the thinking of non-legal actors in disputes where they are the decision-makers. Small claims, with its preponderance of unrepresented parties, provides an ideal setting. The study described below took place with people referred to mediation in Scotland's civil courts. The research question is: 'What is the place of justice in the thinking of small claims mediation participants?'

3) The study

Scotland

Scotland is an unusual jurisdiction. A nation with a thousand year history (Davis 1999, 263-5), union with England in 1707 meant that for almost 300 years Scotland had its own legal system 2 without its own legislature (Smith, 1970) until 1999, when the Scottish Parliament was re-established. Its highest civil court is in London. Scots law, with roots in European canon and civil law (Reid, 2008), has thus been overlaid with judicial decisions reflecting the English common law tradition and is now generally categorised as a 'mixed' legal system (Reid, 2003; but see Osler, 2007).

Scotland also stands apart from a striking recent development across the common law world: the growth in ADR (King et al., 2014). Despite the passage of the Arbitration (Scotland) Act 2010 only 22 arbitrations took place between July 2013 and June 2014 
in a country of 5.4 million people (Auchie et al., 2015). And after positive early endorsement of family mediation, including confidentiality legislation (Civil Evidence (Family Mediation) (Scotland) Act 1995), judges and much of the legal profession have shown indifference or hostility towards general civil mediation (Ross, 2006; Ross and Bain, 2010; Clark, 2011). In contrast to the Woolf reforms in England and Wales, the last major review of Scottish civil justice rejected judicial encouragement for ADR (Report of the Scottish Civil Courts Review, 2009, 172-3; Irvine, 2010). Mediation is attempted in less that $1 \%$ of non-family civil litigation (Civil Justice Statistics in Scotland 2015-16, 62). A senior Scottish judge (now on the UK Supreme Court) typifies judicial attitudes: 'it would not be right to require persons who wish a legal solution of their dispute to participate in a process which is far from pure in its application of legal principle' (Lord Reed 2007, cited in Irvine, 2012).

Nonetheless some within the justice system favour greater use of ADR. In 2013 the Law Society issued guidance to the effect that solicitors should be able to advise clients on ADR options (Law Society of Scotland, Guidance in relation to Rules B1.4, B1.9: Dispute Resolution). Scotland's Employment Tribunals have offered judicial mediation since 2009. A small claims mediation scheme has existed in Edinburgh Sheriff Court since 1998. And in 2016 new rules came into force requiring judges to encourage ADR in actions of up to $£ 5,000$ (Act of Sederunt (Simple Procedure) 2016, SSI 2016/200), a significant and surprising innovation (Irvine, 2016).

What lies in the future for ADR in Scotland is hard to predict. The simple procedure rules were followed by similar encouragement for ADR in commercial actions (Court of Session Practice Note 1 of 2017 - Commercial Actions, 11). Yet this is absent from 
the general civil procedure rules (Scottish Civil Justice Council, 2017) and a 2013 review of the costs of litigation managed to avoid a single reference to ADR in its 334 pages (Taylor, 2013). There is evidence that wider debates about the efficacy and fairness of ADR have influenced Scottish policymakers (Irvine, 2010). There has, however, been a notable lack of empirical research into mediation in Scotland's civil justice system.

To address this gap I initiated a qualitative study of small claims mediation in Glasgow and Edinburgh Sheriff Courts. The pilot phase took place in 2016 under the older, Small Claims, rules. Sheriffs (judges) referred cases to mediation at a procedural hearing; parties were encouraged but not compelled to take part. The full study, including parties referred to mediation under the new Simple Procedure rules, is currently underway.

\section{Methodology}

A philosophical difficulty is engendered by applying social science methods to matters falling within law's domain. Law seeks to provide a normative system applicable to everyday life (McCoubrey and White, 1996). It is prescriptive. Its epistemology is deductive, enabling those skilled in its methods to deduce what is just in particular situations (Halpin, 2006).

Justice is both a psychological and legal concern. However, insofar as courts and other legal actors seek binding rules from justice events they engage in a form of ontological transformation (Teubner, 1989): subjective judgements about disputes become sources 
applicable across whole societies and, in the process, acquire objectivity. The doctrine of legal precedent crystallises this transformation, providing a public good argument for dispute resolution via courts: 'from the moment a body of precedents is formed, an unlimited number of individuals can make use of this legal corpus and derive from it the entire diversity of attendant utilities' (Bilsky and Fisher, 2014, 82). The doctrine of legal positivism, seeing law as rules, reinforces the idea that justice can only come from official sources (Farrell, 2006; Dwyer, 2008; Samuel, 2009).

Social science, whether realist or idealist, tends to reject normativity in favour of description. Its epistemology is inductive (Ritchie et al., 2014): phenomena need to be observed prior to the development of theory and principles. The constructivist turn sees the social world as produced by social interaction, and subject to revision (Grix, 2010). Thus the empirical study of legal matters faces a challenge that is both principled and practical: how to avoid diminishing either law's deductive, normative approach or the inductive, descriptive tradition of the social sciences. Legal scholars run the risks of a closed system, uncorrected by empirical data. And social scientists risk discounting legal ontology, missing law's normative intentions (Pavlakos, 2004). The study described in this article can be located within empirical legal studies (Menkel-Meadow 2006; Hillyard 2007; Webley 2010; Epstein and Martin 2014), defined as "the study through direct methods of the operation and impact of law and legal processes in society" (Genn, Partington and Wheeler, 2006, 3).

The complexity of the research question (examining both justice and thinking about justice) lends itself to a qualitative approach: semi-structured interviews (King, 2004; Ritchie et al., 2014, 4). In this interpretive tradition reality is viewed as subjective, and 
mediated by senses and consciousness. Language does not simply describe the world but shapes our view of what can exist. Meaning is not discovered; it is constructed by "interaction between consciousness and the world... truth is a consensus formed by coconstructors" (Scotland 2012, p.12). Interviews explored the life history of disputes, from their inception in 'naming, blaming and claiming' (Felstiner, Abel and Sarat, 1981) through the raising of court action and the experience of mediation to resolution or otherwise.

Participants were individuals taking part in small claims mediation in Scotland's two largest courts (Glasgow and Edinburgh Sheriff Courts). During the pilot phase I conducted five face-to-face interviews. None of the cases had a value greater that $£ 3,000$. Three concerned unpaid bills, one goods and services and one a landlord/property agent dispute. Three settled and two did not. Three participants were male and two female. None was legally represented in mediation, although one employed a lawyer for court hearings.

Interviews lasted an average of 46 minutes and were semi-structured. They were recorded, transcribed, then analysed using thematic analysis (Miles, Huberman and Saldana, 2014). The goal of this approach is to build theory rather than to test it, so as to remain open to new insights emerging from the data (Ajjawi and Higgs, 2007).

Findings

These are grouped in themes and illustrated by extracts from the data. Four follow justice issues identified in the literature review: procedural justice, fairness and justice 
(goals), fairness and justice (evaluation) and the limitations of mediation. A fifth, unanticipated, theme emerged and is included for its explanatory power in relation to mediation's success: participants' self-presentation.

a) Procedural justice

Researchers have generally been willing to cede to lay people the capacity to determine the fairness of a process (as distinct from its outcome): most procedural justice research is conducted with non-lawyers (see 2(d) above). Before examining substantive justice, it is valuable to consider whether participants believed they had been fairly treated; Welsh (2002) sees this as a baseline or minimum standard for mediation.

These Scottish participants appeared to believe their voice had been heard. One said: 'It gave me an opportunity to put my point across.'

However, being heard by the mediator was less important than being heard by their opponent:

'It gave an opportunity cos, prior to that point, you, you're not having conversations directly with the other party.'

'I can't remember who spoke first but we both did speak and we spoke quite a lot, you know what I mean.'3

This runs counter to much procedural justice research, where the legitimacy of a process turns on the behaviour of an authority figure/decision-maker (though see Nesbit, 3 Unless indicated otherwise all quotations are from individuals who were also pursuers (plaintiffs). 
Nabatchi and Bingham, 2012, for a similar finding). In a process where parties are themselves decision-makers fairness may depend more on the opportunity to be heard by one's counterpart.

b) Fairness and justice - goals

Respondents were asked about their goals for raising or defending a small claim. Their answers reveal a wide range of considerations, including pragmatism, principle, complaints handling, risk, hassle, precedent and even the public interest, similar to those of represented parties in Relis's (2007) study of Canadian medical negligence mediation.

For example, one participant appeared to have some form of precedent in mind:

'Those judgements collectively, if they're used properly, can actually improve things.'

A business defender, whose case had not settled, spoke of the importance of good complaints handling:

'You know, kind of... are we being responsible? Have we been professional? Because sometimes we do things wrong and if we do things wrong I think that it's fair that we have to offer some form of compensation for it.'

Another participant reflected a principle embedded in Scots law: restitution, where a person harmed by another is restored to the position they would otherwise have enjoyed: 
'I'm quite happy to take... not be out of pocket from what I intended.'

c) Fairness and justice - evaluation

At the heart of the research lies the question of substantive justice: did lay people see the mediation outcome as fair and/or just? Interviews employed both terms given their rather different meanings (see 2 (c) i above). As well as discussing fairness, participants were asked the direct question, 'Did you get justice?' One woman, who settled for considerably less than she claimed, replied:

'I think I got more than justice. I think I got, em... I don't want to say teach him a lesson but, you know he, he needed to learn that he can't just get away with things.'

This statement reflects not so much a punitive motivation as a didactic one: people learn lessons from justice events and the financial penalty drives the lesson home.

If the other party was seen as particularly blameworthy, for example a professional who should adhere to higher standards, the punitive motivation was fiercer:

'I'd actually said to the lawyer... look even if this costs me $£ 5000$ it doesn't matter because what they have done is despicable... And this woman's a lawyer, she should know better. Well, had she been a lay person, I might have taken a different view.' 
This response echoes findings that medical negligence claimants sought a large monetary award not (or not only) for compensation but to punish and deter errant doctors (Relis, 2009).

At the same time a distinctive feature of mediation is that outcomes are consensual. No matter how strongly one party feels they must also convince the other to settle. The punitive urge could thus be tempered by pragmatism and a sense of reasonableness:

'Did I feel that he could have gone a bit further? Well, I took a view - it's reasonable we're meeting in the middle, can he be squeezed any more? And knowing [Defender] I thought, well, you could well squeeze him and he'll go the other way. So a bird in the hand...'

'.. there was justice. Absolute justice, if there is such a term, would have been that I would have got the full amount.'

Unsurprisingly mediators played a part in brokering these settlements. One response chimes with US research revealing mediators' focus on lowering client aspirations (Wall and Kressel, 2017):

'...the only reason I think anyone would accept a vastly reduced sum, because that's what it is, in mediation would be because the mediator's saying, look, when you go to court, it's a 50/50, there's no guarantees (LAUGHS) one way or the other... and it's probably not worth the aggro... You'd be as well accepting it.' 
This excerpt illustrates the complex decision-making unrepresented people face in mediation. They must juggle their sense of how much they are entitled to, the practical challenges they face in recovering it ('the aggro'), the risk of failure ('no guarantees') and the effort already expended in getting the other party to offer anything at all - the sunk costs of time spent on the case.

One source of the concern that lay people will settle for 'less' is the view that natural sympathies will cloud their judgment in ways to which judges are inured (Maroney, 2011). Participants did demonstrate signs of empathy, but responses indicate a careful weighing up of competing factors rather than a straightforward emotional reaction.

'I felt he was quite vulnerable and he was quite... he'd just got a, a new baby and... I just thought, well, he's learned his lesson basically, he'll not do that in a hurry again.'

Another described how the Defenders, a medium sized company, had sent a young graduate to represent them. Apparently this influenced his decision to mediate:

'I thought - this lad's wet behind the ears, this could be a good thing to go for it (LAUGHS).'

Such tactical considerations may seem unconnected to either fairness or justice, but will be recognisable to legal professionals versed in the idea of litigation as a game (Galanter, 1974; Bok, 1983). Unrepresented people can also take a strategic view of dispute resolution processes.

d) Mediation's limitations 
One participant with a positive view of the outcome nonetheless spoke of wishing for a more public setting.

'...one slight regret I've got on that moral issue of somebody challenging their terms and conditions and such like in court and getting them to understand it... there was a lack of, em, ombudsman type services that could have done a quasilegal review... there was this jump from the one to one, sort of, between myself and the company... then the next redress had to be at the small claims level rather than at a level beneath. And that was a gap I felt...'

This small claimant echoes concerns about ADR's privacy and the loss of a public declaration of norms (2(a) above). He suggests that an ombudsman scheme, a 'level beneath' the courts, could ensure that companies are publicly named and shamed to discourage them from repeating offending behaviour. While this perspective highlights a troubling issue for mediation, it underlines the point that 'lay' people's justice reasoning extends beyond their immediate interests.

e) Fairness and justice - self-presentation

As well as reporting what is said, qualitative research emphasises the work language is doing: 'the world is made, not found' (Pearce, 2006, 7). Respondents do not simply relate objective facts; they co-construct, with the interviewer, a version of reality that may fulfil other purposes. This was evident in participants' statements about the fairness of their own actions: 
'I said, this is where I will meet and I said, I think this is fair. I said, I will meet in the middle and it's $£ 500$.'

'It's made me feel as if I'm, eh, quite a nice person, to be quite honest with you. I'm fair... it's my personal position, you know what I mean. I, I dislike social injustice. I really dislike it. So I'm quite thingmy ${ }_{4}$ on things like that.'

'I didn't chase them for the 5 hours delay. I chased them for the extra cost beyond that which... which had been incurred.'

Here the respondent demonstrates his own fairness by describing what he could have sued for but didn't. Mediators often hear this sort of self-justification. It speaks of the need to be seen as fair, not only by others, but also in one's own self-image; these may be factors in the eventual outcome.

Participants tended to provide arguments for evaluating their own behaviour, potentially attempting to convince the interviewer ('the tribunal of the man without') and perhaps themselves ('the tribunal of the man within') (Smith, 1759/1976, 130-131) of their fairness. They were thus not only evaluating the outcome but also their own contribution to it, and answering a question not put to them: "what kind of person are you?' This species of question has been found particularly influential in motivating people to participate in mediation (Sikveland and Stokoe, 2016, 247). It may play an equally strong role in achieving settlement. By the time disputes reach the courts 
parties may not care what their adversary thinks, but probably want to be seen in a good light by the mediator (despite claims of impartiality). Clearly they also want to see themselves in a good light.

f) What do the findings tell us?

These findings contradict the idea of mediation as simple horse-trading between two financial positions; rather it is a complex web of factors and people. In the next section I propose ways of conceptualising ordinary people's justice reasoning.

4) Discussion: how might we account for lay people's answers to questions about justice in mediation?

a) The Social Construction of Fairness and Justice

Ordinary citizens faced with the opportunity to negotiate substantive outcomes to their disputes described a wide range of criteria to explain or justify their decisions. These included: recompense for loss; punishment of bad behaviour; teaching someone a lesson (deterring future poor behaviour); holding businesses to account; pragmatism (how far the other party can be pushed); risk of further proceedings; empathy for the other party; reasonableness; and the urge to be, or be seen to be, a fair person.

In the diagram below this complex matrix of decision-making is conceptualised as a multi-party negotiation. Parties negotiate with the mediator; the other party; their supporters; the wider community; and, to an extent, themselves. All of these 
conversations may be one-way (monologue) two-way (dialogue) or include three or more parties (facilitated dialogue); and may be private or public. Wider society is also shown. One practice model, narrative mediation (Winslade and Monk, 2002), overtly acknowledges the impact of societal discourse on possible outcomes.

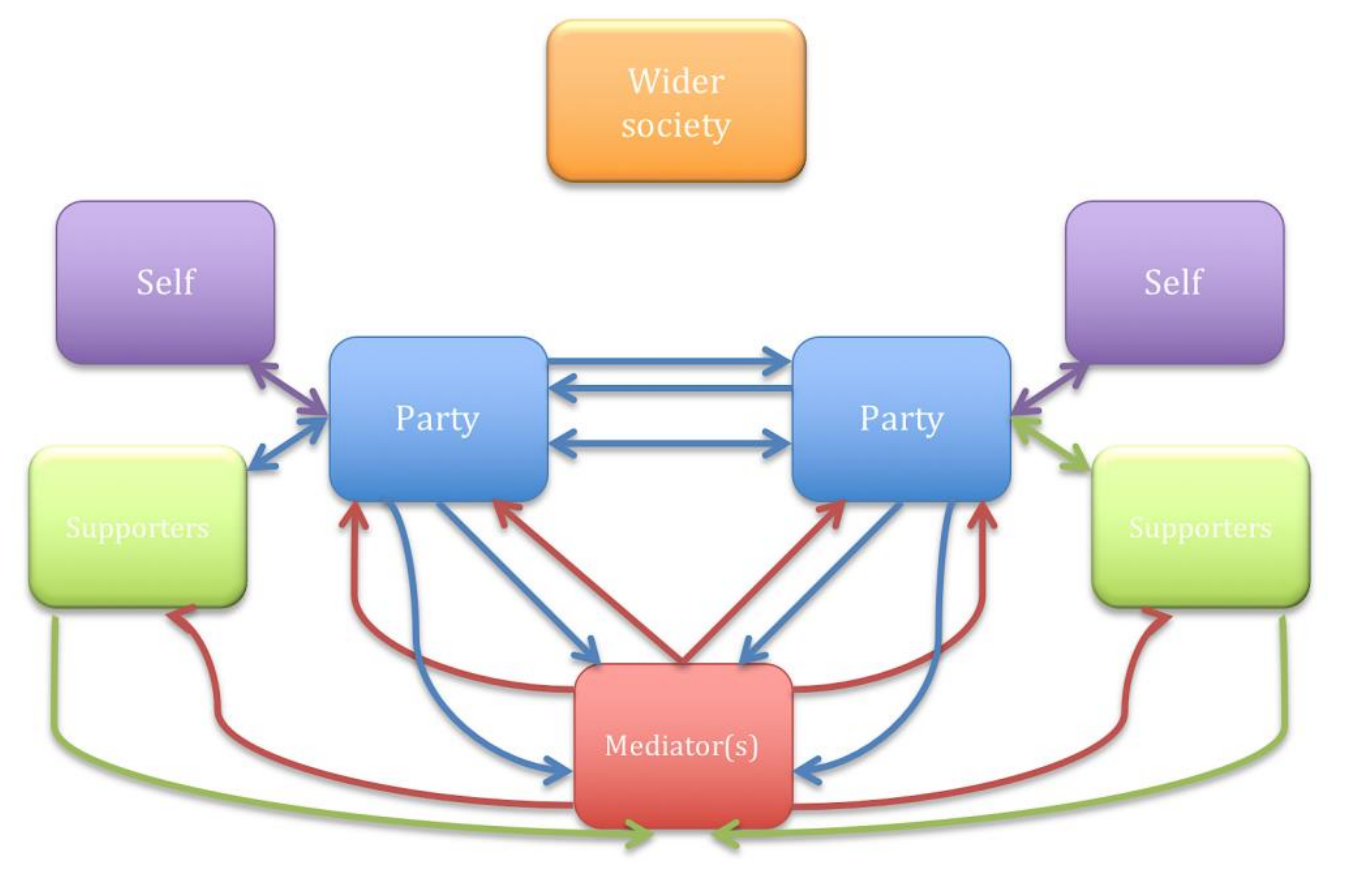

Figure 1: Matrix of Fairness and Justice Negotiation 
In this negotiation process, as in real-world litigation, fairness is not fixed. It is a social construction (Macfarlane, 2001; Paul and Dunlop, 2014) refined through discourse: the interaction provided by the mediation setting. Court judgments are also socially constructed (Silbey, 2005; Schauer, 2006; Finnis, 2011). Judges often disagree in significant cases and minority reports present plausible counter-arguments. Judicial opinions are addressed as much to the wider legal system as to litigants.

Judges, however, are disinterested participants in legal disputes. By contrast, the model above presents mediation as a multi-party negotiation involving interested parties (litigants, representatives, supporters) and a disinterested facilitator (the mediator). Does this prevent it from arriving at just outcomes? While the results have been characterised as 'subjective' (see 2, C, ii above), Seul (2004) argues that negotiated settlements are capable of producing outcomes that are as just, from a societal viewpoint, as those produced by trials. Sturm proposes that court-ordered conflict resolution by non-legal actors can result in 'efficient, fair, and workable norms' (2005, p. 50).

\section{b) Implications for Theories of Justice}

Justice overlaps with, but is not identical to, legality (Gardner, 2018). While the 'shadow of the law' plays an important part in lawyer negotiation (Mnookin and Kornhauser, 1979) justice exists outside the legal system. Society could not function if the courts had to be consulted on every decision touching on fairness and justice, and the adversarial system has long encouraged negotiated settlements (Galanter, 1988). Mediation parties may indeed be ill-informed about legal rules; participants in the 
present study made little mention of the law. They appealed to ethical or moral norms: holding bad behaviour to account; achieving restitution; teaching the offender a lesson; behaving fairly; discouraging others from behaving badly. They also displayed tactical awareness (not unlike legal practitioners): exploiting inexperience, not provoking resistance, assessing the costs and benefits of continuing the dispute.

Alasdair MacIntyre once complained that academic philosophy had become so complex most people believed it had nothing to offer them: 'The attempted professionalization of serious and systematic thinking has had a disastrous effect upon our culture' $(1988, \mathrm{x})$. That accusation could equally be levelled at law and lawyers. The professionalization of serious and systematic thinking about justice is not a new endeavour (Pound, 1944), but it may blind us to other sites of justice reasoning.

Critical work on ADR, emanating largely from the legal academy, tends to replicate the hierarchical structure of the justice system itself: 'superior' courts at the top, supported by a pyramid of appellate and ordinary courts; below them another pyramid of legal professionals; at the bottom 'lay' people (Kennedy, 1982; Arthurs, 1985). Those people's capacity for serious and systematic thinking, or indeed any thinking about justice, is generally regarded through a lens of paternalistic concern. Raz noted law's claim to 'provide the general framework for all aspects of social life' $(1975,154)$. In this view, if non-lawyers do think about justice it is only to advance their own cause or avoid trouble.

The law's hierarchical logic may derive from another era when its purpose was 'to ensure deference by the lower orders to the world-view of the higher' (Arthurs, 1985, 
6). Galanter also notes 'the pretensions of the official law to stand in a relationship of hierarchic control to other normative orderings in society' $(1981,20)$. It seems oddly out of step with contemporary democratic societies where each vote carries equal weight and little deference remains. Mediation's early pioneers made great play of its egalitarian and democratic credentials (Menkel-Meadow, 1991, 6). Critics, however, have tended to portray this as naïve, warning that empowering ordinary people to make their own decisions would simply lead to exploitation of the vulnerable (see 2 (a) ii above). The idea that lay people might be capable of producing just results seems not to have occurred to them, far less that those results may have derived from a set of norms that includes, but is not limited to, the law.

This may be because jurisprudence, the theory of law, struggles to account for 'bottomup' normativity. The hierarchical universe set out by Arthurs is evident within legal positivism with its efforts to derive rules from a 'basic norm' (Kelsen, 1967, 46) or 'ultimate rule of recognition' (Hart, 1961, 100). One of legal positivism's avowed goals is to keep law separate from everyday moral reasoning, to study what law is rather than what it ought to be (Kelsen, 1934, 477). Non-lawyers' views about fairness and justice are thus rendered interesting but irrelevant.

The ancient natural law tradition may prove more apt in conceptualising lay people's thinking about justice. The idea of discerning how just the law is goes back at least to the time of Plato (Rommen, 1936/1998), but it was the Roman jurist Cicero who most clearly articulated the role of human reason in this endeavour:

True law is right reason in agreement with nature; it is of universal application, unchanging and everlasting; ... We cannot be freed from its obligations by 
senate or people, and we need not look outside ourselves for an expounder or interpreter of it (1961, III, xxii).

Cicero sees law as deriving from everyday moral reasoning rather than superior to it. Later natural law theory is associated with religion, but rationality remained central. Scots Law's founding father, Viscount Stair, declared 'Law is the dictate of reason' (Stair, 1681, 1, 1, 1). As Europe secularised following the Enlightenment the role of reason in justice was articulated afresh. Adam Smith saw our sense of justice as innate and mysterious: 'somehow or other, we feel ourselves to be in a peculiar manner tied, bound and obliged to the observation of justice' $(1759 / 1976,80)$. Later natural lawyers lend support to the idea that moral reasoning about justice precedes rather than derives from legal rules. Fuller refers to 'the morality that makes law possible' $(1969,89)$.

This article does not seek to revisit the complex debate between natural law theory and legal positivism. A natural law approach, however, does have potential in accounting for the role of justice in mediation. It links reason and justice and brings both to bear in evaluating substantive legal rules (as do contemporary lawyers, claims Gordon, 1999). It seems a good fit with mediation models which place the parties as decisionmakers and express faith in human rationality (Irvine, 2007). Other approaches may also prove fruitful, such as identity theory (Stets and Osborn, 2008), the notion of moral community (Deutsch, 2014) or Gilligan's (1982) ethic of care/ethic of justice dichotomy.

C) Limitations 
The small sample means further investigation is needed to test its conclusions (the full study of 24 participants is underway). Scotland's new Simple Procedure rules mandate greater judicial encouragement for alternative dispute resolution (Scottish Statutory Instruments, 2016). Thus they create ideal conditions for enriching our understanding of ordinary people's thinking about a justice event in which they are primary decisionmakers. Further research should examine non-lawyers' thinking about justice in other contexts and cultures.

\section{6) Conclusion}

Scotland provides a distinctive backdrop for the empirical study of mediation and justice. Its legal institutions have until now provided little encouragement for alternatives to litigation. It is therefore a useful setting in which to consider the perspectives of mediation participants with few preconceptions and a distinct lack of lawyer briefing.

Despite Genn's (2012a) ringing dismissal of mediation as having anything to do with justice, the concept is central to much mediation and conflict resolution literature. The formal justice system is a key battleground, with critics alleging the process dilutes cherished values like the right to a fair trial while appearing to empower individuals. While lay people's views have been widely canvassed on procedural justice, researchers have tended to leave substantive justice to lawyers. Genn et al's (2007) study devotes nine pages to lawyers' views on mediation and three to those of the parties. 
If we are to account for ordinary people's thinking about justice we need a thicker description than the lay/professional distinction. To characterise that thinking as subjective is to grant legal rules an objectivity belied by the existence of courts and disputes. Natural law theory, with its emphasis on human rationality, may provide a foundation for conceptualising non-lawyers' justice reasoning; legal positivism seems likely to reject that reasoning as failing to emanate from or contribute to legal rules (Gordon, 1999).

To return to the question posed in the title, the lay people in this study seem not to consider ignorance of legal rules a barrier to achieving justice. They have their own criteria for evaluating whether they got a fair result; Figure 1 (above) characterises this as a complex internal and external negotiation. As for whether they got justice, most conceded mixed feelings: on one hand not 'absolute justice'; on the other 'more than justice'. I do not suggest that lay people's thinking on justice should supplant legal rules. Mediation does, however, offer an opportunity for justice to be co-constructed between disputing parties, advisors, mediators, the courts and wider society. 


\section{REFERENCES}

Abel R L (1982) The contradictions of informal justice. In Abel, Richard L (ed.) The Politics of Informal Justice, Vol. 1. The American Experience. New York: Academic Press 267-320.

Ajjawi R and Higgs J (2007) Using Hermeneutic Phenomenology to Investigate How Experienced Practitioners Learn to Communicate Clinical Reasoning. The Qualitative Report 12, 612-638.

Aristotle (no date) The Nichomachean Ethics. Internet Classics Archive. Available at: http://classics.mit.edu/index.html.

Arthurs H W (1985) Without the Law: Administrative Justice and Legal Pluralism in Nineteenth Century. Toronto: University of Toronto Press.

Astor H (2007) Mediator neutrality: making sense of theory and practice. Social and Legal Studies 16, 221-239.

Auchie D P et al (2015) The Scottish Arbitration Survey. Edinburgh. Available at https://www.lawscot.org.uk/media/544422/Scottish-Arbitration-Survey-June2015.pdf (Accessed: 5 January 2019).

Auerbach J S (1983) Justice Without Law: Resolving Disputes Without Lawyers. Oxford: Oxford University Press.

Beer J and Packard C (2012) The Mediator's Handbook. Revised an. Gabriola Island, BC: New Society Publishers.

Belhorn S R (2005) Settling Beyond the Shadow of the Law: How Mediation Can Make the Most of Social Norms. Ohio State Journal on Dispute Resolution 20, 9811026.

Bilsky L and Fisher T (2014) Rethinking settlement. Theoretical Inquiries in Law 15, 77-123. 
Bok D C (1983) A Flawed System of Law Practice and Training. Journal of Legal Education 33, 570-585.

Bollen K Ittner H and Euwema M C (2012) Mediating hierarchical labor conflicts: procedural justice makes a difference - for subordinates. Group Decision and Negotiation 21, 621-636.

Bourdieu P (1987) The force of law : toward a sociology of the juridical field. Hastings Law Journal 38, 814-853.

Brockner J et al (2001) Culture and procedural justice: The influence of power distance on reactions to voice. Journal of Experimental Social Psychology 37, 300315.

Budnitz M E (1994) Arbitration of disputes between consumers and financial institutions: a serious threat to consumer protection. Ohio State Journal on Dispute Resolution 10, 267-342.

Bush R A B and Folger J (1994) The Promise of Mediation: the Transformative Approach to Conflict. San Francisco: Jossey-Bass.

Bush R A B and Folger J (2005) The Promise of Mediation: the transformative approach to conflict. 2nd edn. San Francisco: Jossey-Bass.

Cappelletti M (1993) Alternative Dispute Resolution Processes within the Framework of the World-Wide Access-to- Justice Movement. The Modern Law Review 56, 282-296.

Carmichael N G (2013) The extent (or limit) of mediator influence to effect settlement. Dispute Resolution Journal 68, 21-32.

Charkoudian L Eisenberg D T and Walter J L (2017) What difference does ADR make? Comparison of ADR and trial outcomes in small claims court. Conflict Resolution Quarterly. 
Cicero (1961) The Republic. Translated by C. Keyes. Cambridge, MA: Harvard University Press.

Clark B (2011) Lawyers' resistance to mediation: a Scottish perspective. Rediscovering Mediation in the 21st century. Kuala Lumpur 1-12.

Coben J R (2004) Gollum, meet Smeagol: a schizophrenic rumination on mediator values beyond self-determination and neutrality. Cardozo Journal of Conflict Resolution 5, 65-86.

Cohen A J (2009a) Dispute Systems Design, Neoliberalism, and the Problem of Scale. Public Law and Legal Theory Working Paper Series 14, 51-80.

Cohen A J (2009b) Revisiting Against Settlement: Some Reflections on Dispute Resolution and Public Values. Fordham Law Review 78, 1143-1170.

Colatrella M T (2014) Informed consent in mediation: promoting pro se parties' informed settlement choice while honoring the mediator's ethical duties. Cardozo Journal of Conflict Resolution 15, 705-775.

Collett J L (2008) Is procedural justice enough? Affect, attribution, and conflict in alternative dispute resolution. In Hegtvedt, K. A. and Clay-Warner, J. (eds) Advances in Group Processes: Justice. Bingley, UK: Emerald Group Publishing Ltd 267-289. Coy P G and Hedeen T (2005) A stage model of social movement co-optation: Community mediation in the United States. Sociological Quarterly 46, 405-435. Creutzfeldt N and Bradford B (2016) Dispute Resolution Outside of Courts: Procedural Justice and Decision Acceptance Among Users of Ombuds1 Services in the Uk. Law and Society Review 50, 985-1016.

Delgado R et al (1985) Fairness and formality: minimizing the risk of prejudice in alternative dispute resolution. Wisconsin Law Review 6, 1359-1404.

Delgado R (1988) ADR and the Dispossessed : Recent Books About the 
Deformalization Movement. Law and Social Inquiry 13, 145-154.

Deutsch M (2014) Justice and Conflict. In Coleman, P. T., Deutsch, M., and Marcus, E. C. (eds) The Handbook of Conflict Resolution: Theory and Practice. 3rd edn. San Francisco: Jossey-Bass 29-55.

Dwyer D (2008) Beyond Kelsen and Hart? MacCormick's Institutions of Law. Modern Law Review 71, 823-839.

Eisenberg D T (2016) What We Know ( and Need to Know ) About Court- Annexed Dispute Resolution. South Carolina Law Review. (Legal Studies Research Paper) 67, $1-18$.

Engle-Merry S (1990) Getting Justice and Getting Even: Legal Consciousness among Working-Class Americans. Chicago: University of Chicago Press. Available at: www.press.uchicago.edu.

Engle-Merry S (1993) Sorting Out Popular Justice. In Merry, S. E. (ed.) The Possiblity of Popular Justice. Ann Arbor: University of Michigan Press 31-66.

Erlanger H S and Klegon D A (1978) Socialization effects of professional school: the law school experience and student orientations to public interest concerns. Law \& Society Review 13, 11-35.

Farrell I P (2006) H.L.A. Hart and the Methodology of Jurisprudence. Texas Law Review 84, 983-1011.

Felstiner W L F Abel R L and Sarat A (1981) The emergence and transformation of disputes: naming, blaming, claiming... Law and Society Review 15, 631-654.

Finnis J (2011) Philosophy of Law: Introduction. Available at http://ssrn.com/abstract=1850674 (Accessed: 7 September 2018).

Fiss O (1984) Against Settlement. The Yale Law Journal 93, 1073-1090.

Foucault M (1980) Power/Knowledge: Selected Interviews and Other Writings, 
1972-1977. New York: Random House.

Frey M A (2000) Does ADR Offer Second Class Justice? Tulsa Law Journal 36, $727-766$.

Fuller L (1969) The Morality of Law. Revised Ed. New Haven, CT: Yale University Press.

Fuller L (1971) Mediation: its forms and functions. Southern California Law Review 44, 305-339.

Galanter M (1974) Why the haves come out ahead: speculations on the limits of legal change. Law and Society Review 9, 95-160.

Galanter M (1981) Justice in many rooms: courts, private ordering, and indigenous law. Journal of Legal Pluralism 19, 1.

Galanter M (1988) Quality of Settlements, The. Journal of Dispute Resolution 1988, $55-84$.

Galanter M (2004) The Vanishing Trial: An Examination of Trials and Related Matters in Federal and State Courts. Journal of Empirical Legal Studies 1, 459-570.

Gardner J (2018) The Twilight of Legality. University of Oxford Legal Research Paper, 4/2018. Oxford.

Genn H et al (2007) Twisting arms: court referred and court linked mediation under judicial pressure. London. Available at https://webarchive.nationalarchives.gov.uk/20110201151141/http://www.justice.gov. uk/publications/docs/Twisting-arms-mediation-report-Genn-et-al.pdf (Accessed: 7 January 2019).

Genn H (2012a) What is civil justice for? Reform, ADR, and access to justice. Yale Journal of Law and the Humanities 24, 397-417.

Genn H (2012b) Why the privatization of civil justice is a rule of law issue. London. 
Available at https://www.ucl.ac.uk/laws/judicial-institute/layout-

components/36th_F_A_Mann_Lecture_19.11.12_Professor_Hazel_Genn.pdf

(Accessed: 9 September 2018).

Genn H Partington M and Wheeler S (2006) Law in the Real World: Improving

Our Understanding of How Law Works. Final Report and Recommendations.

London. Available at https://www.nuffieldfoundation.org/sites/default/files/Law in the Real World full report.pdf (Accessed: 11 June 2018).

Gilligan C (1982) In a Difference Voice: Psychological Theory and Women's Development. Cambridge, MA: Harvard University Press.

Gordon R (1999) Radical Conservatism of The Practice of Justice, The. Stan. L. Rev. 51, 919-933.

Greatbatch D and Dingwall R (1989) Selective facilitation: some preliminary observations on a strategy used by divorce mediators. Law and Society Review 23, $613-642$.

Grillo T (1991) The mediation alternative: process dangers for women. Yale Law Journal 100, 1545-1610.

Grix J (2010) The Foundations of Research. 2nd edn. Basingstoke: Palgrave Macmillan.

Halpin A (2006) The Methodology of Jurisprudence : Thirty Years Off the Point. Canadian Journal of Law and Jurisprudence 67, 67-105.

Harrington C B (1982) Delegalisation reform movements: a historical analysis. In Abel, R. L. (ed.) The Politics of Informal Justice, Vol. 1. The American Experience. New York: American Press.

Hart H L A (1961) The Concept of Law. Oxford: Clarendon Press.

Haynes J and Haynes G (1989) Mediating Divorce: Casebook of Strategies for 
Successful Family Mediation. San Francisco: Jossey-Bass.

Hyman J M (2014) Swimming in the deep end: dealing with justice in mediation.

Cardozo Journal of Conflict Resolution 6, 19-56.

Hyman J M and Love L P (2002) If Portia Were a Mediator: An Inquiry into Justice in Mediation. Clinical Law Review 9.

Irvine C (2007) Mediation's values: an examination of the values behind five mediation texts. Birkbeck University of London: Available at:

https://papers.ssrn.com/sol3/papers.cfm?abstract_id=1686195: (Accessed: 12 January 2019).

Irvine C (2010) The sound of one hand clapping: the Gill Review's faint praise for mediation. Edinburgh Law Review 14, 85-92.

Irvine C (2012) Scotland's 'mixed' feelings about mediation. SSRN eLibrary 2-7.

Irvine C (2015) Lawyers of the future on mediation: threat or promise? Kluwer Mediation Blog. Available at:

http://mediationblog.kluwerarbitration.com/2015/06/14/lawyers-of-the-future-onmediation-threat-or-a-promise/ (Accessed: 4 January 2019).

Irvine C (2016) And finally... some plain English from Scotland. Kluwer Mediation Blog. Available at: http://mediationblog.kluwerarbitration.com/2016/09/10/andfinally-some-good-news-from-scotland/ (Accessed: 7 January 2019).

Kelsen H (1934) The pure theory of law: its method and fundamental concepts. Law Quarterly Review 50, 474-498.

Kelsen H (1967) The Pure Theory of Law. 2nd edn. Translated by M. Knight.

Oakland, CA: University of California Press.

Kennedy D (1982) Legal Education and the Reproduction of Hierarchy. Journal of Legal Education 32, 591-615. 
King M et al (2014) Non-adversarial Justice. 2nd edn. Leichardt, NSW: Federation Press.

King N (2004) Using Interviews in Qualitative Research. In Cassell, C. and Symon, G. (eds) Essential Guide to Qualitative Methods in Organizational Research. London: Sage 11-23.

Korobkin R B (2005) The Role of Law in Settlement. In Moffitt, M. and Bordone, R. (eds) The Handbook of Dispute Resolution. San Francisco: Jossey-Bass 254-276.

Lande J (2005) Shifting the Focus From the Myth of 'the Vanishing Trial' To Complex Conflict Management Systems, or I Learned Almost Everything I Need To Know About Conflict Resolution From Marc Galanter. Cardozo Journal of Conflict Resolution 6, 191.

Leveson S B (2015) Security and Justice. Court and Tribunals Judiciary. Available at: https://www.judiciary.gov.uk/announcements/speech-by-sir-brian-levesonsecurity-and-justice/.

Lind E A (2001) Fairness heuristic theory: Justice judgments as pivotal cognitions in organizational relations. In Greenberg, J. and Cropanzano, R. (eds) Advances in Organizational Justice. Stanford, CA: Stanford University Press 56-88.

Lind E A and Arndt C (2017) Regulations, fairness and trust. In OECD (ed.) Trust and Public Policy: How Better Governance Can Help Rebuild Public Trust. Paris: OECD Publishing 67-85.

Lord Thomas of Cwmgiedd $\mathbf{L} \mathbf{C} \mathbf{J}$ of $\mathbf{E}$ and W (2015) The centrality of justice: its contribution to society, and its delivery. Lord Williams of Mostyn Memorial Lecture. London: Courts and Tribunals Judiciary 1-19.

Luban D (1995) Settlements and the erosion of the public realm. Georgetown Law Journal 83, 2619-2662. 
MacCoun R J (2005) Voice, Control and Belonging: The Double-Edged Sword of Procedural Fairness. Annual Review of Law and Social Science 1, 171-201.

Macfarlane J (2001) Why Do People Settle? McGill Law Journal 46, 663-711.

MacIntyre A (1988) Whose Justice, Which Rationality? London: Duckworth.

Maroney T A (2011) The persistent cultural script of judicial dispassion. California Law Review 99, 629-681.

Maroney T A (2012) Angry Judges. Vanderbilt Law Review 65, 1205-1286.

Mayer B et al (2012) Core Values of Dispute Resolution: Is Neutrality Necessary? Marquette Law Review 95, 805-828.

Mayer B (2012) The Dynamics of Conflict: A Guide to Engagement and Intervention. 2nd edn. San Francisco: Jossey-Bass.

McCoubrey H and White N D (1996) Textbook on Jurisprudence. 2nd edn. London: Blackstone Press Ltd.

McGregor L (2015) Alternative Dispute Resolution and Human Rights: Developing a Rights-Based Approach through the ECHR. European Journal of International Law 26, 607-634.

Menkel-Meadow C (1991) Pursuing settlement in an adversary culture: a tale of innovation co-opted or 'the law of ADR'. Florida State University Law Review 19, 147.

Menkel-Meadow C (1997) What Trina taught me: reflections on mediation, inequality, teaching and life. Minnesota Law Review 81, 1413-1428.

Menkel-Meadow C (2006) Empirical studies of ADR: the baseline problem of what ADR is and what it is compared to. In Cane, P. and Kritzer, H. (eds) Oxford Handbook of Empirical Legal Studies. Oxford: Oxford University Press 1-48. Miles M B Huberman A M and Saldana J (2014) Qualitative Data Analysis: A 
Methods Sourcebook. 3rd edn. Thousand Oaks, CA: Sage Publishing.

Mnookin R H and Kornhauser L (1979) Bargaining in the Shadow of the Law: The

Case of Divorce. Yale Law Journal 88, 950-997.

Moore C W (1986) The Mediation Process: Practical Strategies for Resolving Conflict. San Francisco: Jossey-Bass.

Moore C W (2014) The Mediation Process: Practical Strategies for Resolving Conflict. 4th edn. San Francisco: Jossey-Bass.

Mulcahy L (2000) Between the devil and the deep blue sea? A critique of the ability of community mediation to suppress and facilitate participation in civil life. Journal of Law and Society 27, 133-150.

Mulcahy L (2013) The collective interest in private dispute resolution. Oxford Journal of Legal Studies 33, 59-80.

Nader L (1979) Disputing Without the Force of Law. The Yale Law Journal 88, 9981021.

Nesbit R Nabatchi T and Bingham L B (2012) Employees, Supervisors, and Workplace Mediation. Review of Public Personnel Administration 32, 260-287.

Nolan-Haley J (1999) Informed consent in mediation: a guiding principle for truly educated decisionmaking. Notre Dame Law Review 74, 775-840.

Nolan-Haley J and Annor-Ohene J K (2014) Procedural justice beyond borders: mediation in Ghana. Harvard Negotiation Law Review Online 1-19.

Noone M A and Ojelabi L A (2014) Ensuring Access to Justice in Mediation within the Civil Justice System. Monash University Law Review 40, 528-563.

Osler D (2007) The Fantasy Men. Rechtsgeschichte 10, 169-193.

Paul G D and Dunlop J A (2014) The other voice in the room: restorative justice faciliators' constructions of justice. Conflict Resolution Quarterly 31, 257-283. 
Pavlakos G (2004) Normativity v ontology: law, facts and practical reason.

Rechtstheorie 34, 393-420.

Pearce W B (2006) Doing Research From the Perspective of the Coordinated Management of Meaning (CMM). Santa Barbara, CA. Available at https://www.taosinstitute.net/Websites/taos/files/Content/5692988/Overview_of_CM M_in_Research_version_2.0.pdf (Accessed: 10 June 2018).

Perschbacher R R and Bassett D L (2004) The end of law. Boston University Law Review 84, 1-62.

Pound R (1944) What is a Profession - the Rise of the Legal Profession in Antiquity. Notre Dame Law Review 19, 203-228.

Quintanilla V D Allen R A and Hirt E R (2017) The Signaling Effect of Pro se Status. Law and Social Inquiry 42, 1091-1121.

Raz J (1975) Practical Reason and Norms. London: Hutchinson \& Co.

Reda D S (2010) Critical conflicts between first-wave and feminist critical approaches to alternative dispute resolution. Texas Journal of Women and the Law 20, $193-229$.

Reid D (2008) Thomas Aquinas and Viscount Stair : the Influence of Scholastic Moral Theology on Stair's Account of Restitution and Recompense. Journal of Legal History 29, 189-214.

Reid K G C (2003) Idea of Mixed Legal Systems, The. Tulane Law Review 78, 5-40. Relis T (2007) 'It's Not About the Money!': A Theory on Misconceptions of Plaintiff's Litigation Aims. University of Pittsburgh Law Review 68, 701-746. Relis T (2009) Perceptions in Litigation and Mediation: Lawyers, Defendants, Plaintiffs, and Gendered Parties. Cambridge: Cambridge University Press.

Resnik J (2002) Mediating Preferences: Litigant Preferences for Process and Judicial 
Preferences for Settlement. J. Disp. Resol. 2002, 155-169.

Rifkin J Millen J and Cobb S (1991) Toward a New Discourse for Mediation: A

Critique of Neutrality. Mediation Quarterly 9, 151-164.

Riskin L (2005) Replacing the Mediator Orientation Grids, Again : The New New

Grid System. Alternatives 23, 127-132.

Riskin L L (1996) Understanding mediators' orientations, strategies, and techniques:

a grid for the perplexed. Harvard Negotiation Law Review 1, 7-52.

Ritchie J et al (2014) Qualitative Research Practice: a guide for social science students and researchers. 2nd edn. London: Sage Publications Ltd.

Roberts S and Palmer M (2005) Dispute Processes: ADR and the Primary Forms of Decision-Making. Cambridge: Cambridge University Press.

Rommen H (1998) The Natural Law. Translated by T. R. Hanley. Indianapolis:

Liberty Fund.

Ross M and Bain D (2010) Report on evaluation of in court mediation schemes in Glasgow and Aberdeen Sheriff Courts. Scottish Government Social Research. Edinburgh.

Ross M L (2006) Mediation in Scotland: An Elusive Opportunity? In Alexander, N.

(ed.) Global Trends in Mediation. 2nd edn. Alphen aan den Rijn, Netherlands:

Kluwer Law International B. V. 305-331.

Rubinson R (2016) Of grids and gatekeepers: the socioeconomics of mediation. Cardozo Journal of Conflict Resolution 17, 873-907.

Ryder S E (2015) In the shadow of Magna Carta. Courts and Tribunals Judiciary. Available at: https://www.judiciary.gov.uk/announcements/speech-by-sir-ernestryder-in-the-shadow-of-magna-carta/ (Accessed: 14 September 2018).

Sabatino J M (1998) ADR as 'Litigation Lite': Procedural and Evidentiary Norms 
Embedded Within Alternative Dispute Resolution. Emory Law Journal 47, 12891349.

Samuel G (2009) Interdisciplinarity and the Authority Paradigm: Should Law Be Taken Seriously by Scientists and Social Scientists? Journal of Law and Society 36, $431-459$.

Sandefur R L (2008) Access to Civil Justice and Race, Class, and Gender Inequality. Annual Review of Sociology 34, 339-358.

Sander F E A (1985) Alternative methods of dispute resolution: an overview.

University of Florida Law Review 37, 1-18.

Sarat A (1990) ‘...The Law Is All Over’: Power, resistance and the legal consciousness of the welfare poor. Yale Journal of Law \& the Humanities 2, 343-379. Schauer F (2006) Do cases make bad law? U. Chi. L. Rev. 73, 883-918.

Schwartz J R (1999) Laymen cannot lawyer, but is mediation the practice of law? Cardozo Law Journal 20, 1715-1746.

Scotland J (2012) Exploring the philosophical underpinnings of research: Relating ontology and epistemology to the methodology and methods of the scientific, interpretive, and critical research paradigms. English Language Teaching 5, 9-16. Scottish Civil Courts Review (2009) Report of the Scottish Civil Courts Review. Edinburgh.

Scottish Civil Justice Council (2017) The New Civil Procedure Rules: First Report. Available at http://www.scottishciviljusticecouncil.gov.uk/docs/librariesprovider4/consultations/sc jc-consultations/the-new-civil-procedure-rules---first-report-and-annex.pdf?sfvrsn=2 (Accessed: 10 January 2019).

Scottish Statutory Instruments (2016) SHERIFF COURT Act of Sederunt ( Simple 
Procedure ) 2016. Edinburgh.

Seron C et al (2001) The Impact of Legal Counsel on Outcomes for Poor Tenants in New York City's Housing Court : Results of a Randomized Experiment. Law and Society Review 35, 419-434.

Seth R (2000) Mediation: The Great Equalizer? A Critical Theory Analysis.

Seul J R (2004) Settling signficant cases. Washington Law Review 79, 881-968.

Shestowsky D and Brett J (2008) Disputants' perceptions of dispute resolution procedures: an ex ante and ex post longitudinal empirical study. Connecticut Law Review 41, 63-107.

Shiner L (1982) Reading Foucault: anti-method and the genealogy of powerknowledge. History and Theory 21, 382-398.

Sikveland R and Stokoe E (2016) Dealing with resistance in initial intake and inquiry calls to mediation: the power of 'willing'. Conflict Resolution Quarterly 33, $235-254$.

Silbey S S (2005) After Legal Consciousness. Annual Review of Law and Social Science 1, 323-368.

Singer L R (1979) Nonjudicial Dispute Resolution Mechanisms: The Effects on Justice for the Poor. Clearinghouse Review 13, 569.

Smith A (1759) The Theory of Moral Sentiments. 1976th edn. Oxford: Clarendon Press.

Smith T B (1970) Scottish Nationalism, Law and Self-Government. In Neil McCormack (ed.) The Scottish Debate. London: OUP.

Solum L B (2005) Procedural Justice. Southern California Law Review 78, 181-322. Stair (1681) Institutions of the Law of Scotland. 1832 Edn. Edinburgh: Bell and Bradfute. 
Stets J E and Osborn S N (2008) Injustice and emotions using identity theory. Advances in Group Processes 25, 151-179.

Stulberg J B (2012) Must a mediator be neutral ? You'd better believe it! Marquette Law Review 95, 829-858.

Stulberg J P (1998) Fairness and Mediation. Ohio State Journal on Dispute Resolution 13, 909-945.

Stulberg J P (2005) Mediation and Justice : What Standards Govern? Cardozo Journal of Conflict Resolution 6, 1-44.

Sturm S (2005) Law's Role in Addressing Complex Discrimination. In Neilson, L. B. and Nelson, R. L. (eds) Handbook of Employment Discrimination Research. Dordrecht: Springer 35-57.

Tamanaha B Z (2019) The Promise and Conundrums of Pluralist Jurisprudence. The Modern Law Review 82, 159-179.

Taylor J A (2013) Review of Expenses and Funding of Civil Litigation in Scotland Report. Edinburgh. Available at https://www2.gov.scot/Publications/2013/10/8023/5 (Accessed: 14 September 2018).

Teubner G (1989) How the law thinks: toward a constructivist epistemology of law. Law and Society Review 23, 727-758.

Tyler T R (2006) Why People Obey the Law. Princeton: Princeton University Press. Waldman E (2004) The Concept of Justice in Mediation: A Psychobiography. Cardozo Journal of Conflict Resolution 6, 247-271.

Waldman E A (1997) Identifying the role of social norms in mediation: a multiple model approach. Hastings Law Journal 48, 703-769.

Waldman E and Ojelabi L A (2016) Mediators and substantive justice: a view from Rawls' original position. Ohio State Journal on Dispute Resolution 30, 391-430. 
Wall J A and Chan-Serafin S (2014) Friendly persuasion in civil case mediations. Conflict Resolution Quarterly 31, 285-303.

Wall J A and Kressel K (2017) Mediator thinking in civil cases. Conflict Resolution Quarterly 34, 331-367.

Webley L (2010) Qualitative approaches to empirical legal research. In Cane, P. and Kritzer, H. (eds) Oxford Handbook of Empirical Legal Research. Oxford: Oxford University Press 1-21.

Weinstein J B (1996) Some benefits and risks of privatization of justice through ADR. Ohio State Journal on Dispute Resolution 11, 241-295.

Welsh N a (2002) Disputants' decision control in court-connected mediation: a hollow promise without procedural justice. Journal of Dispute Resolution 1, 179-192. Welsh N A (2001) Making Deals in Court-Connected Mediation: What's Justice Got To Do with It. Washington University Law Quarterly 79, 787-861.

Wexler S (1970) Practicing law for poor people. The Yale Law Journal 79, 10491067.

Wheeler C (2014) What is 'fair' and ' reasonable' depends a lot on your perspective. Australian Journal of Administrative Law 22, 63-76.

Whittemore R Chase S K and Mandle C L (2001) Validity in qualitative research. Qualitative Health Research 11, 522-537.

Wilson B and Wilson A (2006) Why is fairness 'grubby?' - semantics, etymology, and perspectives in dispute resolution. Texas Wesleyan Law Review 13, 795-817. Winslade J and Monk G (2002) A Narrative Approach In Mediation. Context 63, 912.

Wissler R L et al (2002) Cout-Connected Mediation in General Civil Cases: What We Know from Empirical Research. Ohio State Journal On Dispute Resolution 17, 
641.

Yoon A (2009) Importance of Litigant Wealth. DePaul L. Rev. 59, 649-673. 